\title{
Antibacterial activity of betel (Piper betle L.) fruit against Pseudomonas aeruginosa
}

\author{
Annisa Hamka', Fatimawali ${ }^{*}$, Olvie S. Datu', Trina E. Tallei ${ }^{2}$ \\ 'Pharmacy Study Program, Faculty of Mathematics and Natural Sciences, Sam Ratulangi University, Manado 95115, Indonesia \\ ${ }^{2}$ Department of Biology, Faculty of Mathematics and Natural Sciences, Sam Ratulangi University, Manado 95115, Indonesia \\ "Corresponding author: Pharmacy Study Program, Faculty of Mathematics and Natural Sciences, Sam Ratulangi University, \\ Manado 95115, Indonesia. Email: fatimawali@unsrat.ac.id
}

\begin{abstract}
Background: Betel (Piper betle L.) is a well-known medicinal plant for its numerous health benefits. Saponins, flavonoids, polyphenols, and essential oils are among the chemical constituents of betel plants. Flavonoids are one of the most common groups of secondary metabolites found in plant tissues, including in betel plants.

Objective: The purpose of this research is to isolate flavonoids from betel fruit and to determine the antibacterial activity of betel fruit extract against Pseudomonas aeruginosa.

Methods: Thin layer chromatography (TLC) with the eluent chloroform: methanol: water was used to isolate flavonoids. UV-Vis spectrophotometry was used to determine the presence of flavonoids in betel fruit. The antibacterial activity of extract and TLC-isolates of betel fruit was tested by using the disc method.

Results: TLC analysis resulted in the formation of a brown stain. The UV-Vis spectrophotometry results revealed two absorption bands at $366 \mathrm{~nm}$ and $268 \mathrm{~nm}$, indicating that flavonoids are present in betel fruit. Antibacterial activity test against Pseudomonas aeruginosa bacteria showed that the concentration of $30 \%$ and $60 \%$ of betel fruit extract had strong antibacterial activity.

Conclusion: The results revealed that the betel fruit contains flavonoid compounds, and the extract has medium to strong antibacterial activity.
\end{abstract}

Keywords: antibacterial, flavonoid, betel fruit, piper betle, pseudomonas aeruginosa

\section{Introduction}

Antibiotic-resistant bacteria are becoming more common, necessitating the development of new natural compounds to kill bacteria. Pseudomonas aeruginosa is one of the bacteria that has developed resistance to antibiotics. This bacterium is commonly found in burns, ear infections, and surgical wounds [1].

One of the medicinal plants in Indonesia that can be used as traditional medicine is betel (Piper betle L) [2]. Traditionally, betel has been used to treat thrush, sore throats, coughs, eyewash, vaginal discharge, stop nose bleeding, speed wound healing, and eliminate bad breath. The chemical content of the betel plant is saponins, flavonoids, polyphenols, and essential oils. Flavonoid compounds are thought to have a mechanism of action by denaturing bacterial cell proteins and damaging cell membranes. Flavonoids are one of the secondary metabolites found in plants. This compound can be used as antimicrobial, wound infection medicine, antifungal, antiviral, anticancer, and antitumor.

Betel plants have been reported as antibacterial activity, including their activity against $P$. aeruginosa $[3,4]$. So far, many studies focus on the leaves of betel, although the fruit part has been widely used by people in several areas of North Sulawesi, Indonesia. Therefore, this study aimed to analyze the flavonoid content in betel fruit, as well as to test the antibacterial activity of the betel fruit extract against $P$. aeruginosa. 


\section{Methods}

\section{Sample preparation}

Betel fruits were taken from Airmadidi Atas, North Minahasa Regency, North Sulawesi, Indonesia, with an altitude of 331 meters above sea level with a north latitude of $1^{\circ} 25^{\prime} 46^{\prime \prime}$ and a south latitude of $124^{\circ} 58^{\prime} 56$. The sample was determined as Piper betle L. at the Biology Laboratory of Sam Ratulangi University. Betel fruits were washed, drained, sorted and weighed. Then, they were allowed to dry at room temperature before being mashed into powder and sieved.

\section{Sample extraction}

A total of 420 grams of powder obtained from 1000 grams of fresh fruit was put into a extraction container. The extraction was carried out by immersing the sample with $1260 \mathrm{~mL}$ of ethanol $96 \%$ for $3 \times 24$ hours at room temperature while stirring occasionally. The extraction results were then filtered and the residue was separated from the filtrate. The residue was extracted again with ethanol $96 \%$ for $3 \times 24$ hours. Then, the sample was filtered to obtain a second filtrate. The filtrates obtained were combined and then evaporated at $42^{\circ} \mathrm{C}$ in incubator to obtain a thick extract.

\section{Flavonoid compound isolation}

Isolation of flavonoid compounds was carried out using thin layer chromatography. Sample extract and quercetin as a control were spotted on a previously activated silica gel $\mathrm{F}_{254}$ plate. Elution was carried out with the mobile phase chloroform: methanol: water (65:25:4) [5], then the plate was observed at a wavelength of $365 \mathrm{~nm}$. After that, the stains on the plate were scraped off and analyzed by UV-Vis spectrophotometer. The isolate was centrifuged, then read on a UV-Vis spectrophotometer using methanol as a standard solvent. The spectrum is observed at a wavelength of $200-400 \mathrm{~nm}$ [6].

\section{Antibacterial activity test of betel fruit extract}

Antibacterial activity test uses the disk diffusion method [7]. Ethanol extract of betel fruit was

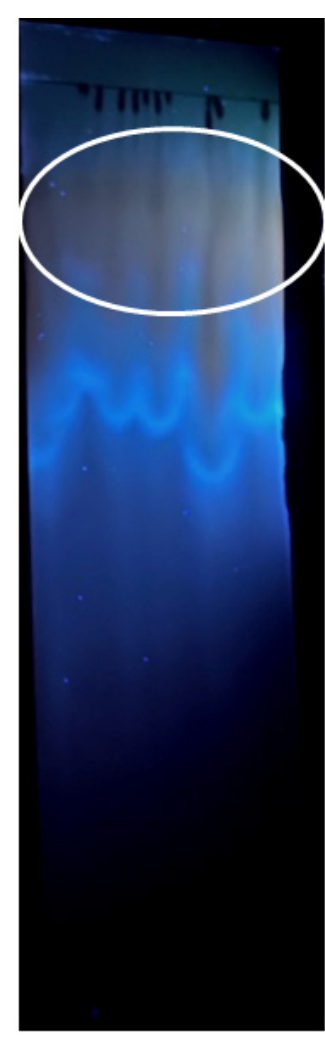

A

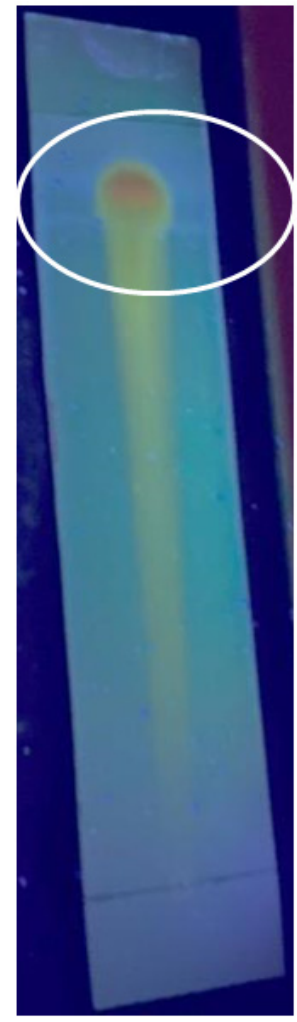

B
Figure 1. TLC results with chloroform: methanol: water (65:25:4). (A) betel fruit thick extract; (B) quercetin

weighed as much as $1.5 \mathrm{~g}$; $3 \mathrm{~g}$; and $6 \mathrm{~g}$, then each was added with $10 \mathrm{ml}$ of distilled water to obtain a concentration of $15 \%, 30 \%$ and $60 \%$. For the negative control solution, sterile distilled water was used. Additionally, as a positive control, paper discs containing the antibiotic chloramphenicol at a concentration of $30 \mu \mathrm{g} /$ disk was used. Pseudomonas aeruginosa ATCC 27833 from pure cultures were taken as much as 1 ose and then grown or inoculated by scratching on slant nutrient agar. Bacterial culture in each agar slant was incubated at $37^{\circ} \mathrm{C}$ for 24 hours. The rejuvenation culture was taken 1 ose in nutrient agar medium then suspended in $0.9 \%$ sodium chloride and shaken.

A total of $100 \mathrm{~mL}$ of liquid nutrient agar was mixed with $3 \mathrm{~mL}$ of bacterial suspension and then put into a petri dish of $30 \mathrm{~mL}$ each and allowed to solidify. Then, using sterile tweezers, each paper disc that has been dripped with the test sample was aseptically placed on the surface of solid nutrient agar. Then the petri dish was 
A

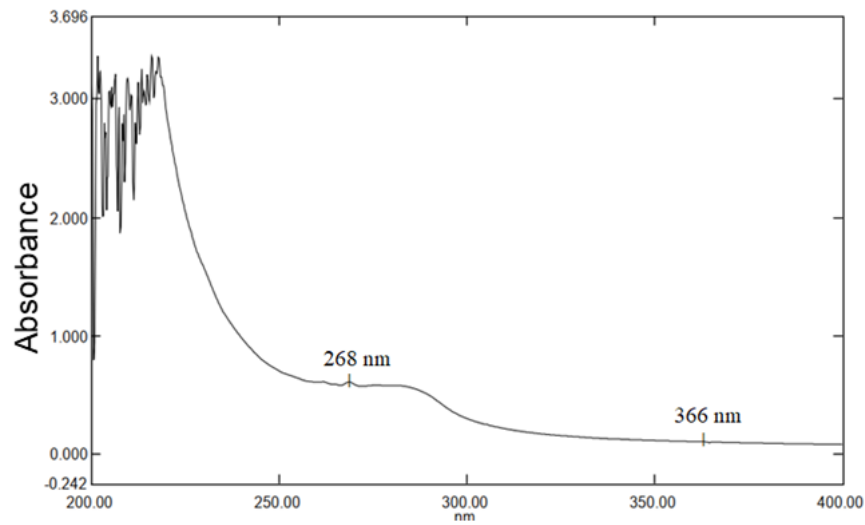

B

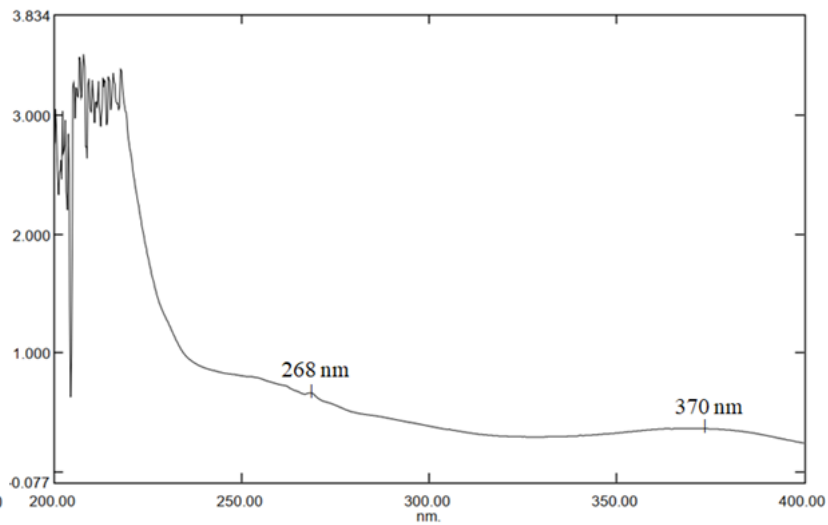

Figure 2. UV-Vis spectrophotometry analysis. (A) betel fruit flavonoid isolation; (B) quercetin

incubated at $37^{\circ} \mathrm{C}$ for $1 \times 24$ hours. The clear zone formed was observed and the diameter of the inhibition zone was measured using a caliper.

\section{Antibacterial activity test of flavonoid compounds}

A total of $100 \mathrm{~mL}$ Mueller Hinton agar (MHA) was sterilized and mixed with $3 \mathrm{~mL}$ bacterial suspension before being poured into $30 \mathrm{~mL}$ petri dishes and allowed to solidify. Each paper disc was dripped with flavonoid samples with concentrations of $15 \%, 30 \%$ and $60 \%$ aseptically using sterile tweezers, then placed on the solid medium. The petri dish was then incubated for $1 \times 24$ hours at $37^{\circ} \mathrm{C}$. The clear zone formed was observed, and the inhibition zone's diameter was determined using a caliper.

\section{Data analysis}

The graphs were generated by using GrapPad Prism 8. The obtained data were subjected to the One-Way ANOVA statistical test and Holm-Sidak multiple comparisons test. $\mathrm{p}<0.05$ was considered significant.

\section{Results}

Isolation of flavonoid compounds from betel fruit extract by thin layer chromatography

A thick extract of $69.27 \mathrm{~g}$ (yield 16.49\%) was obtained from the extraction process using the maceration method. Figure 1 showed that betel fruit extract exhibits a brownish-colored stain when exposed to UV 366 light, whereas quercetin exhibits the same color, indicating the presence of flavonoids. The Rf values obtained were 0.86 and 0.875 for betel fruit extract and quercetin, respectively.

\section{Analysis of isolates with UV-Vis spectrophotometer}

UV-Vis spectrophotometer analysis in visible spectrum, two bands were presented at a wavelength of $366 \mathrm{~nm}$ and at a wavelength of $268 \mathrm{~nm}$ (Figure $2 \mathrm{~A})$. The results obtained have the same absorption range as quercetin (Figure 2B). The first band appeared in the range $350-385 \mathrm{~nm}$, which is $370 \mathrm{~nm}$, and the second band appeared in the range $250-280 \mathrm{~nm}$, which is $268 \mathrm{~nm}$. This further establishes the presence of flavonoids in betel fruit extract. The difference in the wavelength of the band in betel fruit extract and quercetin can be influenced by several factors, such as type of solvent, the $\mathrm{pH}$ of the solution, the concentration of the solution, the thickness of the solution, and the width of the light gap.

\section{Antibacterial activity of betel fruit extract and TLC-isolates}

As shown in Figure 3A, each concentration of betel fruit extract was able to inhibit the growth of $P$. aeruginosa. Concentration of $15 \%$ resulted 


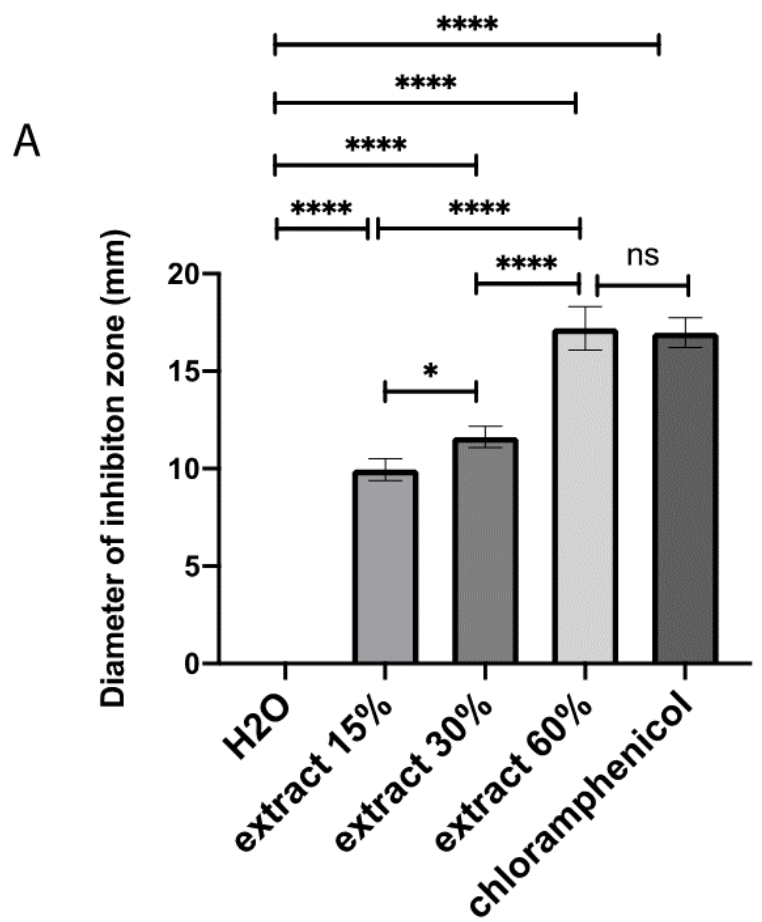

B

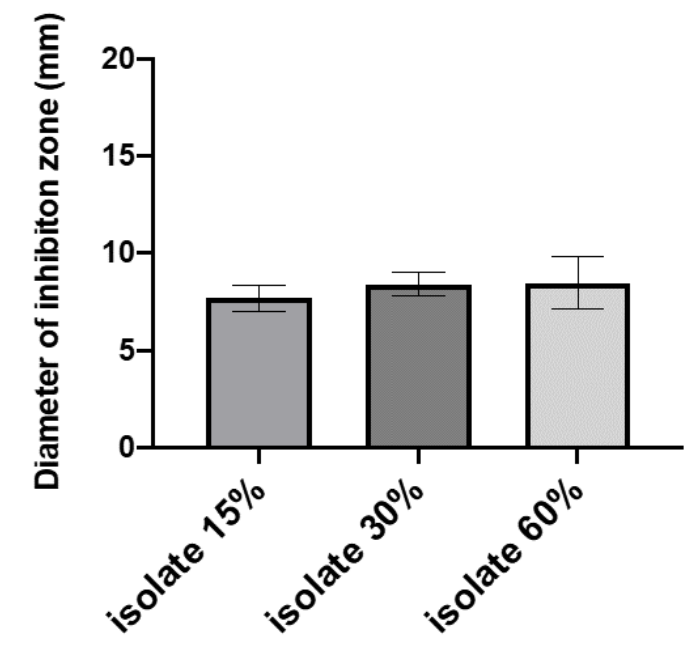

Figure 3. Diameter of inhibition zones as a result of antibacterial activity. (A) betel fruit extract; (B) flavonoid isolated from betel fruit extract

in an inhibition zone diameter of $9.95 \pm 0.550$ $\mathrm{mm}$ (a moderate antibacterial activity), while a concentration of $30 \%$ and $60 \%$ resulted in an inhibition zone with a diameter of $11.63 \pm 0.551$ $\mathrm{mm}$ and $17.20 \pm 1.100 \mathrm{~mm}$, respectively (both have a strong category of antibacterial activity). The negative control did not have an inhibitory zone, while the chloramphenicol (a positive control) had an inhibition zone with diameter $16.97 \pm 0.777 \mathrm{~mm}$ (a strong antibacterial activity). Interestingly, the extract concentration of $60 \%$ equal to chloramphenicol in inhibiting bacterial growth.

The results of antibacterial testing using thin layer chromatography with brown stains (flavonoids from betel fruit extract) are shown in Figure 3B. The results of the isolation from thin layer chromatography were divided into three concentrations, namely $15 \%, 30 \%$ and $60 \%$, and produced an inhibitory zone of $7.68 \mathrm{~mm} ; 8.4 \mathrm{~mm}$, and $8.47 \mathrm{~mm}$ (a medium antibacterial activity). According to the results, this activity is below the extract activity, suggesting not only flavonoid that have contribution to antibacterial activity.

\section{Discussion}

The results of UV-Vis spectrophotometry analysis of isolate showed absorption at wavelengths of 366 $\mathrm{nm}$ and $268 \mathrm{~nm}$, suggesting that the isolate was positive for flavonoids. The absorption spectrum of flavonols has a wavelength of 350-385 $\mathrm{nm}$ in the first band and the second band at a wavelength of 250-280 nm [8].

The results of testing the antibacterial activity of betel fruit extract showed that the higher the concentration the stronger the inhibitory activity, this is in line with betel leaf extract research results $[7,11]$. The bacterial inhibitory is categorized as very strong ( $>20 \mathrm{~mm})$, strong $(10-20 \mathrm{~mm})$, moderate (5-10 mm), weak $(<5 \mathrm{~mm})$ [9]. Based on this category, the betel fruit extract concentration of $15 \%$ which means it has a moderate category of antibacterial activity. While extracts with concentrations of $30 \%$ and $60 \%$ which means that it has a strong category of antibacterial activity. Meanwhile the positive control chloramphenicol has strong antibacterial activity.

The formation of the inhibition zone was caused by the presence of flavonoid secondary metabolite 
compounds contained in the isolate which acted as antibacterial. The difference in the diameter of the inhibition zone formed in the antibacterial activity test between flavonoid isolates and betel fruit extract could be attributed to betel fruit containing several other antibacterial compounds. The number of antibacterial active substances contained in the isolate can cause a difference in the inhibition zone; the more antibacterial compounds in the isolate, the better the isolate works in inhibiting bacterial growth.

In addition to flavonoids, it is possible that other chemical compounds as saponins, polyphenols and essential oils contained in betel extract can contribute to inhibiting the growth of bacteria. Flavonoids can interfere with the permeability of bacterial cells, by forming protein complexes that disrupt the integrity of the bacterial cell membrane [10]. Saponins can increase the permeability of cell membranes so that they can cause lysis or rupture of bacterial cell membranes [11]. Polyphenols are able to damage cell membranes, denature proteins, and inactivate enzymes so that bacterial cell walls will experience a decrease in permeability which can interfere with the exchange of substances needed for metabolism [12]. The antibacterial activity of green betel leaf essential oil is caused by the presence of phenolic compounds and their derivatives that can denature bacterial cell proteins. Based on this study, it was found that the ethanol extract of betel fruits has antibacterial activity.

\section{Conclusion}

The betel fruit extract showed moderate to strong antibacterial activity against Pseudomonas aeruginosa.

\section{Acknowledgment}

This study was funded by DIPA Sam Ratulangi University Ministry of Education, Culture, Research and Technology, through Sam Ratulangi University Applied Excellence Research Schemes (RTUU) 2021.

\section{Author contribution}

Conceptualization, A.H; Methodology, A.H.; Investigation, O.S.D; Writing - Original Draft, A.H.; Writing - Review \& Editing, T.E.L; Supervision, F. All authors have read and agreed to this manuscript.

\section{Declaration of interest}

The authors declare no conflict of interest.

Received: 12 August 2021

Accepted: 28 September 2021

Published online: 18 November 2021

\section{References}

1. Pang Z, Raudonis R, Glick BR, Lin T-J, Cheng Z. Antibiotic resistance in Pseudomonas aeruginosa: mechanisms and alternative therapeutic strategies. Biotechnol Adv. 2019;37: 177-192. https://doi.org/10.1016/i. biotechadv.2018.11.013

2. Zar'ah NA, Syachruddin S, Kusmiyati K. The Effect of Green Betel Leaves (Piper betle L.) Extract on Wounding Healing in Mice (Mus musculus L.). JBT. 2021;21: 103. https://doi.org/10.29303/jbt.v21i1.2282

3. Lubis RR, Marlisa, Wahyuni DD. Antibacterial activity of betle leaf (Piper betle l.) extract on inhibiting Staphylococcus aureus in conjunctivitis patient. Am J Clin Exp Immunol. 2020;9: 1-5.

4. Ermawati FU, Sari R, Putri NP, Rohmawati L, Kusumawati DH, Munasir, et al. Antimicrobial activity analysis of Piper betle Linn leaves extract from Nganjuk, Sidoarjo and Batu against Escherichia coli, Salmonella sp., Staphylococcus aureus and Pseudomonas aeruginosa. J Phys: Conf Ser. 2021;1951: 012004. https://doi.org/10.1088/17426596/1951/1/012004

5. Dewi NLA. Pemisahan, Isolasi, dan Identifikasi Senyawa Saponin Dari Herba Pegagan (Centella asiatica L. Urban). jfu. 2018; 68. https://doi.org/10.24843/IFU.2018.v07. i02.p05

6. Ridwanuloh D, Syarif F. Isolasi dan Identifikasi Senyawa Flavonoid dari Batang Ciplukan (Physalis angulata L.). Pharma Xplore. 2019;4: 288-296. https://doi. org/10.36805/farmasi.v4i1.619

7. Jorgensen JH, Ferraro MJ. Antimicrobial susceptibility testing: a review of general principles and contemporary practices. Clin Infect Dis. 2009;49: 1749-1755. https:// doi.org/10.1086/647952

8. Dewi NWRK, Gunawan IW, Puspawati NM. Isolasi dan Identifikasi Senyawa Antioksidan Golongan Flavonoid dari Ekstrak Etil Asetat Daun Pranijiwa (Euchresta horsfieldii Lesch Benn.). CK. 2017;5: 26. https://doi. org/10.24843/CK.2017.v05.i01.p04 
9. Davis WW, Stout TR. Disc plate method of microbiological antibiotic assay. I. Factors influencing variability and error. Appl Microbiol. 1971;22: 659-665. https://doi. org/10.1128/am.22.4.659-665.1971

10. Yudha C, Karlina Y. Aktivitas Antibakteri Ekstrak Herba Krokot (Portulaca oleracea L.) terhadap Staphylococcus aureus dan Escherichia coli. LenteraBio: Berkala Ilmiah Biologi. 2013; 87-93.
11. Böttger S, Melzig MF. The influence of saponins on cell membrane cholesterol. Bioorg Med Chem. 2013;21: 7118-7124. https://doi.org/10.1016/j.bmc.2013.09.008

12. Makarewicz M, Drożdż I, Tarko T, Duda-Chodak A. The Interactions between Polyphenols and Microorganisms, Especially Gut Microbiota. Antioxidants (Basel). 2021;10. https://doi.org/10.3390/antiox10020188 